\title{
Corruption and Educational Outcomes: Two Steps Forward, One Step Back
}

\author{
FRANCIS L. HUANG \\ University of Virginia
}

\begin{abstract}
Corruption is a problem that continues to plague developed and developing countries worldwide. Previous studies have explored the negative implications of corruption on several aspects of human development, but, despite its serious and long-lasting consequences, the impact of corruption on educational outcomes has started to receive attention only in recent years. This study empirically investigates the relationship between corruption and educational outcomes, using a sample of 50 countries. Study findings show that corruption is negatively associated with educational outcomes, after controlling for other variables, and suggest that continued efforts be made to control corruption.
\end{abstract}

Huang, F. L. (2008). Corruption and Educational Outcomes: Two Steps Forward, One Step Back. International Journal of Education Policy and Leadership 3(9). Retrieved [DATE] from http://www.ijepl.org.

Corruption, defined as the misuse of public office for personal gain (Klitgaard, MacLean-Abaroa, \& Parris, 2001), continues to plague both developed and developing countries worldwide. Corruption flourishes when an organization or a public official has monopoly control over certain goods or services, has discretionary power, and has no accountability (Klitgaard, 1988). ${ }^{1}$ Previous studies have explored the negative implications of corruption on several aspects of human capital and economic development (e.g., Akçay, 2006; Alesina \& Weder, 2002; Gupta, Davoodi, \& Tiongson, 2000; Mauro, 1995, 1998; Transparency International, 2006; Treisman, 2000). Despite its serious and long-lasting consequences, corruption in the educational system is a topic that has started to receive attention only in recent years (Azfar \& Gurgur, 2001; Heyneman, 2004; Rumyantseva, 2005). This study empirically investigated the relationship of corruption on two measures of educational outcomes. The first indicator was a measure of educational quality defined by the country average scores on the Trends in International Mathematics and Science Study (TIMSS) 2003, and the second indicator was a gauge of educational quantity using the United Nations Educational, Scientific, and Cultural Organization's (UNESCO) measure of school life-expectancy (SLE).

\section{Literature Review}

\section{Consequences of Corruption}

The question of whether the presence of corruption is detrimental or beneficial to economic activity sounds ironic, yet it has been a controversial question among some economists (Meon \& Sekkat, 2005). An older school of thought proposed that corruption may promote or "grease the wheels" of growth, suggesting that corruption can have positive effects (Leff, 1964; Nye, 1967). The grease-the-wheels point of view suggested that corruption may compensate for bad governance and remove uncertainty, which may result in increased investments (Leff, 1964). Nye (1967) suggested that corruption may be beneficial for growth under certain conditions, while it can be detrimental in other circumstances. However, Kauffman and Wei (1999), using data from three worldwide firm-level surveys, countered the "efficient grease" theory, finding that firms that paid more in bribes spent more, not less, time with bureaucrats negotiating regulations and had a higher, not lower, cost of capital. More recent empirical investigations on corruption have also focused on the efficiency-reducing aspect of corruption, indicating that corruption "sands the wheels" of growth and reduces economic activity. In a study of 71 countries, Meon and Sekkat (2005) found 
a negative effect of corruption on growth and investment, supporting the sand-the-wheels view of corruption. In one of the earliest studies quantifying the relationship between corruption and growth, Mauro (1995) observed the significant negative relationship between corruption on growth and investment

Other factors that influence economic growth are related to the level of foreign direct investments and the quality and productivity of investments. Habib and Zurawicki (2002) indicated that corruption is a serious deterrent to foreign direct investments and suggested that foreign investors generally avoid corruption because it can create operational inefficiencies. Tanzi and Davoodi (1997) found a negative relationship between corruption and the quality of investments, in which increasing public investment resulted in reduced growth and productivity and, ultimately, lower-quality outputs. Examples include government infrastructure projects costing more than they should but yielding poor results or products.

Corruption's impact on other significant areas of human capital development has also been documented. Gupta, Davoodi, and Alonso-Terme (2002) pointed out that high levels of corruption worsen income inequality and poverty; for example and one standard deviation increase in corruption increases the Gini coefficient of income inequality by an estimated 11 points and reduces income growth of the poor by 4.7 percentage points. Akçay (2006) indicated that, in a study of 63 countries, corruption indices and human development had a statistically significant negative relationship. Because many of the development indicators affected are associated with human capital factors and because a country's economic growth depends on development of its labor force, a negative relationship between corruption and human development may affect a country's overall progress. Several studies have, in fact, focused on the relationship between economic growth and human capital (UNESCO, 2004).

Corruption and poverty are highly correlated (Transparency International, 2006), yet the direction of causality-that is, does corruption cause poverty or poverty cause corruption?-is not always evident. Although some researchers have found a correlation between a country's development and the incidence of corruption (Alesina \& Weder, 2002; Husted, 1999; Treisman, 2000), others found wide variances among groups of countries at similar stages of development (Kauffman, 1997). Still others have investigated whether corrupt governments receive less foreign aid, but such studies have yielded no evidence to support such a con- clusion (Alesina \& Weder, 2002). Although corruption exists in all countries, it tends to be more damaging to poor countries, where it can undermine the rule of law and cripple economic and political developments (Klitgaard et al., 2001). Corruption is a serious problem because it can minimize government revenue-generating efforts while at the same time drain away scarce resources that could otherwise be used for the development of a country's social services and infrastructure (Tanzi \& Davoodi, 1997). In summary, research has shown that corruption reduces economic growth, creates barriers to investment, promotes income inequalities, influences government expenditures, and worsens factors related to overall human development.

\section{Corruption and Education}

Mauro (1997) looked at corruption and its effect on the composition of government expenditures and found that government expenditure on education was negatively and significantly associated with corruption, after controlling for gross domestic product (GDP) per capita. Corrupt countries were found to spend less on education as a percentage of their GDP; Mauro (1998) indicated that if a country improves its corruption index by one standard deviation, government spending on education can increase by around a half percent of GDP. The harm of the lack of investment in education by more corrupt countries is a serious problem (Kauffman, 1997).

In an empirical study of corruption in one developing country, Azfar and Gurgur (2001) found that a disproportionate burden of corruption was placed on the poor and indicated that corruption reduced test scores, lowered national ranking of schools, and raised variation of test results across schools. Gupta, Davoodi, and Tiongson (2000) suggested that corruption increases the cost and lowers the quality of education services.

It is not a surprise that the education sector is a target for corrupt officials, because education is the largest or second-largest budget item in most countries and opportunities for corrupt practices are numerous (U4 Anti-Corruption Resource Centre, 2006). In some countries, education consumes an estimated 30 percent of the national budget, creating a potential wide avenue for corruption (Transparency International, 2006). Corruption in education is by no means limited to certain countries or regions; in fact, a six-year study of more than 60 countries showed that corruption in the education sector is present in countries ranging from those with poorly governed, low-paid staff to affluent Western democracies (Hallak \& Poisson, 2007). 
Corruption in the educational sector can occur at several levels: at the policy level, the ministry or department level, and the school or administrative level. Insufficient resources may be allocated for education as a result of corrupt practices, or resources may be diverted en route to schools. Examples of corruption in the education sector are numerous: ghost schools that do not exist but have expenses that find their way into the pockets of politicians, teachers not showing up for work but collecting salaries, exams being sold to students, and widespread corruption in textbook procurement and school construction that result in books and classrooms costing many times more than they should (Azfar, 2001; Transparency International, 2005). In addition, new opportunities for corruption have been introduced with decentralization, privatization, and outsourcing (UNESCO, 2004). Corruption also affects the moral fabric of societies, undermines incentives for young people to work hard, and teaches easier means to get ahead (Rumyantseva, 2005). Corrupt educational institutions weaken rather than strengthen a nation's social cohesion (Heyneman, 2004). Although corruption in general is a large problem for many countries, corruption in the education sector is even more disturbing, because it undermines the trust and foundation upon which societies are built and takes advantage of those that most need help.

\section{The Study's Research Question}

Studies have suggested that corruption is a systematic feature of many economies and that it constitutes a significant impediment to economic growth (e.g., Azfar, Lee, \& Swamy, 2001; Klitgaard et al., 2001). Other studies have drawn the link between corruption and education (Azfar \& Gurgur, 2001; Heyneman, 2004; Mauro, 1998), but the relationship of corruption to educational outcomes on a cross-country level has yet to be explored. This paper examines the association between the perceived level of corruption and educational outcomes as measured on a country level.

With regard to educational outcomes, such as student achievement, Summers and Wolfe (1977) suggested that achievement $(\mathrm{ACH})$ was a function of a student's genetic background and socioeconomic status (GSES), teacher quality (TQ), nonteacher school quality (SQ), and peer group characteristics (PG). Summers and Wolfe presented the reduced equation as follows: $\mathrm{ACH}=f$ (GSES, TQ, SQ, PG). Because corruption can have an association with contextual, environmental variables such as SES and PG, the main question this study asked was this: Does corruption have a significant association with educational outcomes, after controlling for other variables? The signs of the coefficients were expected to be negative, indicating that higher corruption was associated with lower educational outcomes.

\section{Data and Methods}

This study used several sources of data and focused on two educational outcome measures (i.e., two dependent variables) related to levels of educational quality and quantity. The educational quality outcome was a composite index derived using each country's average science and mathematics scores on the TIMSS 2003. The educational quantity measure used the school life-expectancy (SLE) indicator developed by UNESCO.

\section{Sample}

Fifty countries $(N=50)$ were included in the sample. ${ }^{2}$ Thailand, Canada, and the Czech Republic did not participate in the TIMSS 2003 study, but their scores from the TIMSS 1999 were included in order to increase the limited sample size. Based on World Bank gross national product (GNP) per capita income groupings, ${ }^{3}$ the sample contained two low-income countries (4\%), 15 lowermiddle-income countries (30\%), 13 uppermiddle-income countries (26\%), and 20 high-income countries (40\%).

\section{Dependent Variables}

Educational performance outcomes were measured using the cross-country TIMSS 2003.4 These scores measure $4^{\text {th }}$ and $8^{\text {th }}$ grade students' science and mathematics performance from the countries that participated in the study (Martin, Mullis, \& Chrostowski, 2004). The TIMSS 2003 was a project of the International Association for the Evaluation of Educational Achievement directed by the TIMSS International Study Center. An educational performance index (EPI) was constructed by averaging each country's latest $8^{\text {th }}$ grade TIMSS science and mathematics scores. The EPI $(M=$ $473.87, S D=71.79$ ) was used in place of either science or mathematics $8^{\text {th }}$ grade scores since the subject-area scores were so highly correlated $(r=.95, p<0.001)$. Based on the EPI, the highest-performing countries were Singapore, Taiwan, and South Korea; the lowest performers were South Africa, Ghana, and Saudi Arabia.

For the measure of educational quantity, the study used the SLE 2003 indicator developed by UNESCO. The SLE indicator $(M=14.29, S D=2.62)$ measured the 
average number of years of schooling that a 5-year-old child could expect to receive in the future (Motivans, 2005). School life-expectancy can be used to assess the overall level of performance of an educational system, in terms of average duration of participation. As an average, SLE exhibits variation, since some students spend a great amount of time in school and others never go to school at all. A limitation is that it measures duration of education only in years and does not account for variations in numbers of school hours that students may accumulate during a year. Another limitation is that SLE does not distinguish between students who complete a grade level within one year and those who repeat the grade level, so countries with high repetition levels may have higher SLEs. School life-expectancy can be viewed as a measure of a country's educational progress and provides a "perspective on educational attainment of the adult population in the near future" (UNESCO-UIS/OECD, 2005, p. 21) and it is similar to another commonly used development related indicator, life expectancy at birth. The countries with the highest SLEs were Australia, Belgium, and New Zealand (more than 19 years); the lowest were Ghana, Morocco, and Saudi Arabia (less than 10 years).

\section{Independent Variable}

The main independent variable was corruption as measured by Transparency International's (TI) Corruption Perceptions Index (CPI) $2003(M=4.55, S D=2.34)$. The CPI is an annual composite index that ranks more than 130 countries by perceived levels of corruption (Transparency International, 2003). ${ }^{5}$ Corruption, by its very nature, is a difficult construct to measure because it leaves no paper trail. The CPI is determined by surveys of business people and assessments by country analysts. ${ }^{6}$ In this study, the CPI variable order was reversed for easier interpretation of results; the reordered CPI values indicated that higher figures meant higher perceived levels of corruption (high corruption; maximum rating of 10), while lower figures meant lower perceived levels of corruption (low corruption; minimum rating of 1). The CPI 2003 combined assessments from the past three years in order to reduce large variations in scoring due to random effects. It should be noted that CPI is an overall measure of corruption and does not specifically measure corruption in the education sector. Based on the CPI, the countries that rated the lowest in corruption were Finland, New Zealand, and Singapore; countries that rated the highest on corruption were Indonesia, Serbia, and Macedonia. The expected sign of the CPI coefficient was negative.

\section{Control Variables}

The analyses controlled for the average size of households and the state of freedom in a country. Since several articles have discussed the exceptional performance of countries such as Singapore, Japan, Taiwan, and Hong Kong on the TIMSS (Aun, Riley, Atputhasamy, \& Subramaniam, 2006; House, 2005), a regional dummy variable was used for Asia Pacific (APAC) countries in the sample (excluding Australia/Oceania). The expected sign of the APAC coefficient was positive in terms of educational quality.

In reviewing factors that have an effect on educational performance, Hanushek (1989) found no strong or systematic relationship between school expenditures and school performance. In a review of 377 studies that dealt with input factors that affected education, Hanushek (1997) pointed out that a majority of empirical studies yielded statistically nonsignificant findings for factors such as teacher/pupil ratio, teacher education/salary, expenditure per pupil, and administrative inputs. Instead, family background explained the differences in achievement; on average, children of wealthier parents performed better (Hanushek, 1992). Family inputs included variables such as income, parental education, and family size. Hanushek (1992) asserted that family size directly affects children's achievement scores on tests, indicating that children from smaller households perform better. Country average household size (HHS) was used as a control variable $(M=1.25, S D=.31)$. Since the data were positively skewed (much like GNP per capita), HHS data were transformed using the natural log. Household size data were sourced from Encyclopedia Britannica's Geoanalyzer (2007), for years ranging from 1997 to 2001. Estimates from the most recent year were used in the analysis. The expected sign of the HHS coefficient was negative.

Household size can also be thought of as a proxy variable for the national wealth of a country because HHS and GNP per capita are highly correlated $(r=.60)$, with lower-income countries having more members per household as compared to wealthier nations. GNP per capita is strongly linked with other social and economic indicators of a country; generally, people living in countries with higher GNP per capita tend to have higher literacy rates, longer life expectancies, better access to safe water, and lower infant mortality rates (World Bank Group, 2001). It is important to control for per capita income measures, but due to extremely high multicollinearity with corruption $(r=.87)$, GNP per capita was not directly used in this study as a control variable. ${ }^{7}$ 
In one cross-country study, corruption was found to have a significant effect on several indicators of education services, but once per capita income was added as a control variable, corruption ceased to be significantly correlated with indicators such as primary school enrollment rates and illiteracy rates (Gupta et al., 2000).

In addition, a country's level of political and civil freedom or level of democracy was used as a control variable in this study. Treisman (2000) indicated that a country's long-standing history of democracy could be an important deterrent to corruption, given that countries with a history of democratic governance have built systems of checks and balances over time. For the freedom variable (FREE), Freedom House's Freedom in the World Survey 2003, published in 2004, was used. The survey numerically rated 192 countries and 18 disputed territories in order to create a freedom index $(M=5.4, S D=$ 1.77) based on ratings of political rights and civil liberties. (Political rights referred to the right to participate in the political process; civil liberties referred to freedom to develop opinions, institutions, and personal autonomy without state interference.) The freedom index, an average of both political rights and civil liberties scores, assigned a freedom status to the countries that ranged from "not free" to "free." For this study, the index order was reversed so that countries with low scores (1 minimum) were "not free" and those with high scores (7 maximum) were "free." Although conventional wisdom may suggest that more democratic or freer societies produce better-performing students, in a series of case studies, Carnoy and Samoff (1989) indicated that some socialist states have been more successful in developing highquality mass education than capitalist states. Carnoy and Marshall (2005) stated that authoritarian or corporatist regimes could be highly effective in creating a social context for high economic growth and academic achievement, as was the case in Singapore, Taiwan, and Korea. All descriptive statistics are presented in Table 1 (see page 9).

\section{Analytic Strategy}

To determine whether corruption had a significant relationship with the dependent variables (EPI and SLE), ordinary least squares (OLS) regression models presented in several stages were used. Using OLS has its limitations however and the factors that affect education indicators are often poorly captured by aggregate indicators (Gupta et al., 2000). Bivariate correlations of CPI between EPI and SLE, as well as all control variables, produced baseline regression coefficients. The correlations answered the basic question of this study: Was there an association between corruption and educational outcomes, and, if so, how strong were the associations? The simple correlations, however, did not indicate whether the relationship between corruption and educational outcomes held, once the study controlled for other variables. To better understand this relationship, control variables were then entered one at a time to build the rest of the models. SAS was used to estimate all regression coefficients and a macro was employed to generate White's heteroscedasticity-consistent (HC3) standard error estimates (Hayes \& Cai, in press).

\section{Results}

Bivariate correlations showed the relationship of CPI with the EPI and SLE and all the control variables. As expected, the simple correlations (see Table 2, page 9) between CPI and EPI $(r=-.43, p<.001)$ and SLE $(r=-$ $.75, p<.001)$ were negative and statistically significant ( $\alpha=.05$ ), indicating that countries with higher CPI's had lower EPI and SLE indicators.

The OLS regression models, with all the control variables entered, showed a similar association for both EPI and SLE (see Table 3, page 10). For the EPI in model 4, CPI remained statistically significant $(p=.02)$ even after controlling for HHS, FREE, and APAC. Together, the four variables (CPI, HHS, FREE, and APAC) explained 57 percent of the overall variance in the EPI, $F(4,45)=$ $12.55, p<.001$. Household size and APAC were statistically significant with a negative coefficient for HHS and a positive coefficient for APAC. The FREE coefficient was negative but was not statistically significant $(p>.05)$. For SLE, the CPI coefficient was negative, and it was the only variable that remained statistically significant $(p<.001)$ even after controlling for all other variables. In model 6 , CPI and HHS were both statistically significant, but HHS lost significance $(p>.05)$ once FREE was included in model 7. Together, CPI, HHS, FREE, and APAC in model 8 explained 68 percent of the overall variance in the SLE, $F(4,45)=22.31, p<.001$. In addition, with the SLE regressions, all control variable coefficients were negative but were not statistically significant (all p's > .05).

\section{Discussion}

The statistically significant negative association between corruption and the EPI and SLE_-even after controlling for HHS, FREE, and APAC—-suggests that an increase in corruption is associated with lower educational out- 
comes. On average, a one-point increase in the CPI (an increase in corruption) decreases TIMSS scores by around 8.5 points (or around 11.5 percent of one standard deviation change in the EPI). While not a large effect size, corruption can detract from human capital building efforts. This is in line with previous research that has shown that corruption has been found to lower test scores (Azfar \& Gurgur, 2001). The strong relationship between corruption and household sizes is evident in the results, implying the importance of resource constraints on the quality of education as suggested by Hanushek (1992).

The APAC variable also indicates that, on average, Asia Pacific countries performed better on the EPI by one standard deviation, which is a large effect size. Several interpretations of higher achievement in these nations are possible. For example, it could be a result of a strong Confucian culture, which gives education great importance (Leung, 2002) or a result of strong development policies enacted over time by powerful regimes, as in the case of several "Asian Tigers" (Ramirez, Luo, Schofer, \& Meyer, 2006).

Although not statistically significant, the FREE variable's coefficient indicates that countries with greater freedom and democracy typically score lower on the EPI yet have a greater number of years of expected education, as shown with the SLE variable. Quantity (more years of education) does not necessarily lead to better performance; that is, having more years of education does not automatically mean better quality of learning. Of note is that the countries with the highest TIMSS performance did not have a long-standing history of democracy. Similarly, Akçay (2006) investigated the association of the democracy and corruption variables with human development and also did not find a significant relationship between democracy and human development, after including regional dummy variables.

The negative coefficient associated with SLE suggests that, on average, for every point increase in the CPI, SLE decreases by .65 years (nearly 8 months or around 25 percent of one standard deviation in SLE), holding all other variables constant. In other words, on average, children in more corrupt countries can expect to receive fewer years of schooling. Again, the effect size associated with corruption may not be large, but it is important to emphasize that corruption retains its significance even with the inclusion of the control variables, indicating a strong relationship between corruption and educational outcome measures of quality and quantity. Gupta et al.'s (2000) research indicated that, controlling for other vari- ables, corruption was significantly associated with increased primary school dropout rates. As dropout rates increase, SLE is expected to decrease, as supported by the current study. While HHS and APAC retain their significance in the full EPI model (model 4), no other control variable retains its significance in relation to SLE (model 8). The loss of significance of HHS could imply that the resource constraints associated with a greater number of household members affect educational quality and not the number of years of expected schooling.

\section{Conclusion}

Empirical studies analyzing the effects of corruption have revealed corruption's significant impact on various aspects of human capital and economic development. This study explored the relationship between corruption and educational outcomes (in terms of quality and quantity) in the sample of 50 countries. Results indicated a statistically significant negative relationship between corruption and both TIMSS performance and SLE indicators, while controlling for other variables. Policymakers should pay heed to the potential impact of corruption, especially since, in many instances, education is seen as a means of combating corruption. Ongoing efforts that involve adding resources and finding ways to improve education are critical, but corruption has the potential of holding back or sabotaging a country's educational progress-much like taking two steps forward and one step back. If the economic development of a country is related to its performance in science and mathematics, removing potential roadblocks to progress becomes even more important. Although corruption is an unpleasant and difficult topic to address, turning a blind eye to it does not make it go away but actually encourages it. Eliminating corruption involves a culture change and a shift in mind-set along with implementation of accountability systems and processes. By the very nature of the change, reducing the corruption levels in a country will take time.

Because education is viewed as an important tool in the war against corruption, it becomes increasingly important to focus on controlling corruption and find ways to track and minimize it. In summary, this study contributes to the growing body of knowledge that looks at the relationship between corruption and education and adds to the growing list of corruption's negative consequences. 


\section{Endnotes}

1. Klitgaard uses a stylized equation,

Corruption $=$ Monopoly + Discretion - Accountability.

2. The term "countries" is used even though some areas are actually territories, such as Hong Kong. Countries included Armenia, Australia, Bahrain, Belgium, Botswana, Bulgaria, Canada, Chile, Cyprus, Czech Republic, Egypt, Estonia, Finland, Ghana, Hong Kong, Hungary, Indonesia, Iran, Israel, Italy, Japan, Jordan, Latvia, Lebanon, Lithuania, Macedonia, Malaysia, Moldova, Morocco, Netherlands, New Zealand, Norway, Palestinian National Authority, Philippines, Romania, Russia, Saudi Arabia, Serbia, Singapore, Slovakia, Slovenia, South Africa, South Korea, Spain, Sweden, Taiwan, Thailand, Tunisia, United Kingdom, and the United States.

3. Economies were categorized according to World Bank income groupings based on GNP per capita: low income, $\$ 875$ or less; lower-middle income, \$876-\$3,465; upper-middle income, $\$ 3,466-\$ 10,725$; and high income, $\$ 10,726$ or more.

4. TIMSS is conducted on a four-year cycle: the first round was conducted in 1995 and the second round in 1999.

5. The World Bank constructs a similar yearly corruption index, called the Control of Corruption Index, which is almost perfectly correlated with the CPI $(r=.972)$.

6. Survey sources for the CPI 2003 included Columbia University, the Economist Intelligence Unit, the European Bank for Reconstruction and Development (EBRD), Freedom House, Information International, the Institute for Management and Development (IMD), a multilateral development bank, Political and Economic Risk Consultancy, PricewaterhouseCoopers, Gallup International on behalf of Transparency International, the World Bank, the World Economic Forum, and the World Markets Research Centre.

7. Finding statistical significance with the variables is difficult due to increased standard errors.

\section{References}

Akçay, S. (2006). Corruption and human development. Cato Journal, 26(1), 29-46.

Alesina, A., \& Weder, B. (2002). Do corrupt governments receive less foreign aid? The American Economic Review, 92(4), 1126-1137.

Aun, T., Riley, J., Atputhasamy, L., \& Subramaniam, R. (2006). School science achievement in Japan and Singapore: A tale of two cities. Educational Research for Policy and Practice, 5(1), 1-13.

Azfar, O. (2001). Corruption and the delivery of health and education services. College Park, MD: University of Maryland, Center for Institutional Reform and the Informal Sector (IRIS).
Azfar, O., \& Gurgur, T. (2001). Does corruption affect health and education outcomes in the Philippines? College Park, MD: University of Maryland, Center for Institutional Reform and the Informal Sector (IRIS).

Azfar, O., Lee, Y., \& Swamy, A. (2001). The causes and consequences of corruption. Annals of the American Association of Political and Social Sciences, 573, 42-57.

Carnoy, M., \& Marshall, J. (2005). Cuba's academic performance in comparative perspective. Comparative Education Review, 49(2), 230-261.

Carnoy, M., \& Samoff, J. (1989). Education and social transformation in the third world. Princeton, NJ: Princeton University Press.

Freedom House (2003). Freedom in the World 2003 Edition. Retrieved April 20, 2007, from http://www.freedomhouse.org/template.cfm?page=3 $63 \&$ year $=2003$

Geoanalyzer (2007). Ranked statistics. Retrieved April 19, 2007, from http://www.geoanalyzer.britannica.com/analyst/rank ed

Gupta, S., Davoodi, H., \& Alonso-Terme, R. (2002). Does corruption affect income inequality and poverty? Economics of Governance, 3, 23-45.

Gupta, S., Davoodi, H., \& Tiongson, E. (2000). Corruption and the provision of health care and education services. IMF Working Paper No. 79. Washington, DC: International Monetary Fund.

Habib, M., \& Zurawicki, L. (2002). Corruption and foreign direct investment. Journal of International Business Studies, 33(2), 291-307.

Hallak, J., \& Poisson, M. (2007). Corrupt schools, corrupt universities: What can be done? Paris, France: UNESCO International Institute for Educational Planning. Retrieved October 1, 2007, from http://unpanl.un.org/intradoc/groups/public/documents/UNESCO/UNPAN025403.pdf

Hanushek, E. (1989). The impact of differential expenditures on school performance. Educational Researcher, 18(4), 45-51.

Hanushek, E. (1992). The trade-off between child quantity and quality. The Journal of Political Economy, 100(1), 84-117.

Hanushek, E. (1997). Assessing the effects of school resources on student performance: An update. Educational Evaluation and Policy Analysis, 19(2), 141-164. 
Hayes, A. F., \& Cai, L. (2007). Using heteroskedasticityconsistent standard error estimators in OLS regression: An introduction and software implementation. Behavioral Research Methods, 39(4), 709-722.

Heyneman, S. (2004). Education and corruption. International Journal of Education Development, 24(6), 638-648.

House, J. (2005). Classroom instruction and science achievement in Japan, Hong Kong, and Chinese Taipei: Results from the TIMSS 1999 assessment. International Journal of Instructional Media, 32(3), 295-311.

Husted, B. (1999). Wealth, culture, and corruption. Journal of International Business Studies, 30(2), 23-45.

Kauffman, D. (1997). Corruption: The facts. Foreign Policy, 107, 114-131.

Kauffman, D., \& Wei, S. (1999). Does "grease money" speed up the wheels of commerce? NBER Working Paper 7093. Retrieved April 29, 2007, from http://wwwwds.worldbank.org/servlet/WDSContentServer/WD SP/IB/2000/01/11/000094946_99122306102923/R endered/PDF/multi_page.pdf

Klitgaard, R. (1988). Controlling corruption. Berkeley, CA: University of California Press.

Klitgaard, R., MacLean-Abaroa, R., \& Parris, H. L. (2001). Corrupt cities: A practical guide to cure and prevention. Washington, DC: World Bank Institute.

Leff, N. (1964). Economic development through bureaucratic corruption. American Behavioral Scientist, 8, 8-14.

Leung, F. (2002). Behind the high achievement of East Asian students. Educational Research and Evaluation: An International Journal of Theory and Practice, 8(1), 87-108.

Martin, M., Mullis, I., \& Chrostowski, S. (Eds.). (2004). TIMSS 2003 technical report. Chestnut Hill, MA: TIMSS \& PIRLS International Study Center, Boston College.

Mauro, P. (1995). Corruption and growth. Quarterly Journal of Economics, 110(3), 681-712.

Mauro, P. (1997). Why worry about corruption? Washington, DC: The International Monetary Fund.

Mauro, P. (1998). Corruption and the composition of government expenditure. Journal of Public Economics, 69, 263-279.

Meon, P., \& Sekkat, K. (2005). Does corruption grease or sand the wheels of growth? Public Choice, 122, 69-97.

Motivans, A. (2005). Using educational indicators for policy: School life-expectancy. Prospects, 35(1), 109-116.

Nye, N. (1967). Corruption and political development: A cost-benefit analysis. American Political Science Review, 61, 417-427.

Ramirez, F, Luo, X., Schofer, E., \& Meyer, J. (2006). Student achievement and national economic growth. American Journal of Education, 113, 1-29.

Rumyantseva, N. (2005). Taxonomy of corruption in higher education. Peabody Journal of Education, 80(1), 81-92.

Summers, A., \& Wolfe, B. (1977). Do schools make a difference? The American Economic Review, 67(4), 639-652.

Tanzi, V., \& Davoodi, H. (1997). Corruption, public investment, and growth. IMF Working Paper No. 97/139. Retrieved February 10, 2007, from http://ssrn.com/abstract=882701

Transparency International (2003). Transparency International Corruptions Perceptions Index 2003. Retrieved February 10, 2007 from http://www.transparency.org/content/download/3222/19543/file/cpi2003.pressrelease.en.pdf

Transparency International (2005). Stealing the future: Corruption in the classroom. Retrieved February 10, 2007, from http://www.transparency.org/global_priorities/education/corruption_education

Transparency International (2006). 2006 Corruption Perceptions Index reinforces link between poverty and corruption. Retrieved February 10, 2007, from http://www.transparency.org/news_room/latest_new s/press_releases/2006/en_2006_11_06_cpi_2006

Treisman, D. (2000). The causes of corruption: A crossnational study. Journal of Public Economics, 76, 399-457.

U4 Anti-Corruption Resource Centre (2006). Corruption in the education sector. Retrieved October 14, 2007, from http://www.u4.no/pdf/?file=/themes/education/papers/U4Issue4_2006_corruption_in_education.pdf

United Nations Educational, Scientific, and Cultural Organization (UNESCO) (2004). Education for all: The quality imperative. EFA Global Monitoring Report 2005. Retrieved February 10, 2007, from http://unesdoc.unesco.org/images/0013/001373/13 7333e.pdf 
United Nations Educational, Scientific, and Cultural

Organization-Institute for Statistics/Organisation

for Economic Cooperation and Development

(UNESCO-UIS/OECD) (2005). Education trends in

perspective: Analysis of the world education indicators.

Retrieved February 10, 2007, from

http://www.uis.unesco.org/TEMPLATE/pdf/wei/WEI

2005.pdf

World Bank Group (2001). GNP per capita. Retrieved

April 1, 2007, from http://www.worldbank.org/dep-

web/english/modules/economic/gnp/index.html

\begin{tabular}{|c|c|c|c|c|c|}
\hline Variable & Minimum & Maximum & Mean & Std. Deviation & Source \\
\hline $\begin{array}{l}\text { Educational Performance } \\
\text { Index }\end{array}$ & 254.00 & 592.00 & 473.87 & 71.80 & TIMSS \\
\hline School Life- Expectancy & 7.70 & 20.7 & 14.29 & 2.62 & $\begin{array}{c}\text { UNESCO Institute for } \\
\text { Statistics }\end{array}$ \\
\hline $\begin{array}{l}\text { Corruption Perceptions } \\
\text { Index }\end{array}$ & 1.30 & 9.10 & 5.55 & 2.37 & $\begin{array}{l}\text { Transparency } \\
\text { International }\end{array}$ \\
\hline $\begin{array}{l}\text { Average Household Size } \\
\qquad(\log )\end{array}$ & $\begin{array}{l}2.00 \\
(.69)\end{array}$ & $\begin{array}{l}8.00 \\
(2.08)\end{array}$ & $\begin{array}{l}3.68 \\
(1.25)\end{array}$ & $\begin{array}{l}1.25 \\
(.31)\end{array}$ & $\begin{array}{c}\text { Encyclopedia } \\
\text { Britannica Geoanalyzer }\end{array}$ \\
\hline Freedom & 1.00 & 7.00 & 5.40 & 1.77 & Freedom House \\
\hline Asia Pacific & 0.00 & 1.00 & .18 & .39 & \\
\hline
\end{tabular}

\begin{tabular}{|c|c|c|c|c|c|c|}
\hline Table 2. Bivariate Correlations Among Variables (N $=50)$ & EPI & SLE & CPI & HHS & FREE & APAC \\
\hline Variable & 1 & $.633^{* *}$ & $-.425^{* *}$ & $-.587^{* *}$ & $.373^{* *}$ & $.284^{*}$ \\
\hline Educational Performance Index (EPI) & & 1 & $-749^{* *}$ & $-.596^{* *}$ & $.606^{* *}$ & -.101 \\
\hline School Life Expectancy (SLE) & & & 1 & $.399^{* *}$ & $-.440^{* *}$ & .039 \\
\hline Corruption Perceptions Index (CPI) & & & & 1 & $-.774^{* *}$ & .145 \\
\hline Average Household Size, log (HHS) & & & & & 1 & -.062 \\
\hline Freedom (FREE) & & & & & & 1 \\
\hline$*$ Correlation is significant at the 5 percent level (2-tailed). & & & & \\
\hline$*$ Correlation is significant at the 1 percent level. & & & & & \\
\hline
\end{tabular}




\begin{tabular}{|c|c|c|c|c|c|c|c|c|}
\hline & \multicolumn{8}{|c|}{ Model } \\
\hline Variable & $1^{* *}$ & $2 * *$ & $3 * *$ & $4 * *$ & $5 * *$ & $6 * *$ & $7 * *$ & $8^{* *}$ \\
\hline Corruption & $\begin{array}{c}-13.07^{* *} \\
(3.01)\end{array}$ & $\begin{array}{l}-7.00^{*} \\
(3.52)\end{array}$ & $\begin{array}{l}-8.39 * \\
(4.20)\end{array}$ & $\begin{array}{l}-8.35^{*} \\
(3.53)\end{array}$ & $\begin{array}{c}-.84^{* *} \\
(.10)\end{array}$ & $\begin{array}{c}-.68 * * \\
(.11)\end{array}$ & $\begin{array}{c}-.65^{* *} \\
(.10)\end{array}$ & $\begin{array}{c}-.65^{* *} \\
(.10)\end{array}$ \\
\hline $\begin{array}{l}\text { Average Household } \\
\text { Size (log) }\end{array}$ & & $\begin{array}{c}-114.78 * * \\
(25.77)\end{array}$ & $\begin{array}{c}-162.55^{*} \\
(54.07)\end{array}$ & $\begin{array}{c}-184.32 * \\
(52.59)\end{array}$ & & $\begin{array}{c}-3.01^{*} \\
(.84)\end{array}$ & $\begin{array}{l}-2.00 \\
(1.60)\end{array}$ & $\begin{array}{l}-1.93 \\
(1.70)\end{array}$ \\
\hline Freedom & & & $\begin{array}{l}-11.74 \\
(10.84)\end{array}$ & $\begin{array}{l}-13.68 \\
(9.31)\end{array}$ & & & $\begin{array}{l}-.25 \\
(.26)\end{array}$ & $\begin{array}{l}-.25 \\
(.27)\end{array}$ \\
\hline Asia Pacific (Dummy) & & & & $\begin{array}{c}71.99 * * \\
(22.05)\end{array}$ & & & & $\begin{array}{l}-.23 \\
(.61)\end{array}$ \\
\hline Constant & $\begin{array}{c}546.44 * * \\
(15.95)\end{array}$ & $\begin{array}{c}656.71 * * \\
(26.97)\end{array}$ & $\begin{array}{r}787.79 * * \\
(133.28)\end{array}$ & $\begin{array}{c}812.38 * * \\
(117.61)\end{array}$ & $\begin{array}{l}18.95 * * \\
(.64)\end{array}$ & $\begin{array}{c}21.84 * * \\
(.91)\end{array}$ & $\begin{array}{c}19.09 * * \\
(3.21)\end{array}$ & $\begin{array}{c}19.01 * * \\
(3.38)\end{array}$ \\
\hline $\mathrm{F}$ & 18.80 & 19.28 & 12.42 & 12.55 & 65.12 & 44.49 & 29.52 & 22.31 \\
\hline $\mathrm{R}^{2}$ & .18 & .39 & .42 & .57 & .56 & .67 & .68 & .68 \\
\hline $\begin{array}{c}\mathrm{p} \text {-value } \\
\text { (significance of model) }\end{array}$ & $<.001$ & $<.001$ & $<.001$ & $<.001$ & $<.001$ & $<.001$ & $<.001$ & $<.001$ \\
\hline \multicolumn{9}{|c|}{$\begin{array}{l}\text { Note: Dependent variable is the Educational Performance Index in Models 1-4; } \\
\text { dependent variable is school life-expectancy in models 5-8 (N=50). } \\
\text { *Correlation is significant at the } 5 \text { percent level (2-tailed). Figures in parentheses are } \\
\text { heteroscedasticity-consistent standard errors. A high value in the corruption index indicates higher levels of perceived } \\
\text { corruption. } \\
* \text { Correlation is significant at the } 1 \text { percent level. }\end{array}$} \\
\hline
\end{tabular}

IJEPL is a joint publication of the Association for Supervision and Curriculum Development, the Faculty of Education at Simon Fraser University, and the College of Education and Human Development at George Mason University. By virtue of their appearance in this open access journal, articles are free to use, with proper attribution, in educational and other non-commercial settings 90 days after initial publication. Copyright for articles published in IJEPL is retained by the authors. More information is available on the IJEPL Web site: http://www.ijepl.org 